\title{
De NVMO in de jaren 2007-2012: beleidsvisie voor een volwassen vereniging
}

\author{
Olle ten Cate
}

\section{Inleiding}

De persoonlijke schets die oud-NVMOvoorzitter (19861997) Lennart Bouman in dit nummer van TMO geeft van de ontwikkeling van de NVMO geeft aan hoezeer de vereniging zich heeft ontwikkeld van een kleine enthousiaste groep betrokkenen bij het medisch onderwijs tot een professionele organisatie in 2007. De vereniging is volwassen geworden, met de verantwoordelijkheden die daarbij horen. Dit weerspiegelt zich in het beleid dat het NVMO-bestuur heeft uitgestippeld voor de periode 2007-2012. Het volledige plan waarin dit is neergelegd, en dat is aanvaard door de Algemene Ledenvergadering in november 2006, is te vinden op de website van de vereniging (www.nvmo.nl). In deze bijdrage aan TMO wordt dit beleid beschreven, redactioneel enigszins samengevat en geactualiseerd naar het najaar van 2007.

Het algemene doel van de NVMO is statutair vastgelegd en betreft de bevordering van onderzoek en ontwikkeling van het medisch onderwijs in de ruimste zin. Dit doel wordt enerzijds gerealiseerd door het organiseren van ontmoetingen, vergaderingen en andere bijeenkomsten en anderzijds door het verzamelen, produceren en distribueren van gegevens die alle betrekking hebben op het medisch onderwijs, en via andere middelen die bevorderlijk zijn voor het doel van de vereniging. In het licht van dit doel wordt het volgende beleid voorzien.

\section{Het beleid voor 2007-2012}

De belangstelling in Nederland voor medisch onderwijs, inclusief de medische vervolgopleidingen, groeit aanzienlijk. Dat blijkt uit het toenemende aantal universitaire leerstoelen met een specifieke opdracht in het medisch onderwijs, uit de sterk toenemende hoeveelheid wetenschappelijk onderzoek met internationale publicaties, het aantal promovendi en proefschriften op dit terrein en uit de sterke ontwikkelingen in de medische vervolgopleidingen. In de laatste vijf jaar de afgelopen planperiode - is een grote activiteit op dit terrein ontplooid.

De Nederlandse Vereniging voor Medisch Onderwijs heeft hierin een goede, maar relatief nog bescheiden rol gespeeld. Ook de vereniging ziet een gestage toename van leden, een steeds grotere belangstelling voor het jaarlijkse congres en een toenemende belangstelling vanuit de medische vervolgopleidingen. Zij kan echter een nog duidelijkere plaats krijgen in deze ontwikkelingen. De NVMO wil de vereniging zijn waar iedereen die actief betrokken is bij zowel de uitvoering, ontwikkeling en het onderzoek van medisch onderwijs, als bij de medische en andere opleidingen in de gezondheidszorg in Nederland en Vlaanderen, zich van nature toe aangetrokken voelt, en waarin men zich thuis voelt. Ze wil, meer nog dan in het verleden, actief faciliteiten bieden en een gemeenschap vormen voor uitwisseling van ideeën en initiatieven voor al deze betrokkenen.

De vereniging biedt van oudsher een open en constructief, niet-competitief klimaat dat gericht is op samenwerking om het hogere doel van beter medisch onderwijs te bereiken. Deze lijn wordt voortgezet in de komende planperiode, maar met een actievere benadering en ondersteuning van de doelgroep, via het congres, het tijdschrift, de website en via de werkgroepen en commissies. Hierbij zal internationaal gebruik worden gemaakt van de uitstekende naam die Nederland en Vlaanderen hebben op het gebied van de ontwikkeling en onderzoek van medisch onderwijs. 


\section{Breedte en naamgeving van de vereniging}

Binnen en buiten de NVMO zijn in de afgelopen jaren discussies gevoerd over de breedte van de doelgroep van de vereniging en in verband hiermee over haar naam. Dit heeft niet geleid tot aanpassingen van de naam in de afgelopen 35 jaar, maar het is wel belangrijk de breedte van alle elementen van de naam te benadrukken.

\section{Nederlandse}

Met 'Nederlandse' wordt gedoeld op het Nederlandstalige werkterrein, dat wil zeggen in Nederland en Vlaanderen. Voorts is de NVMO een open vereniging. Het lidmaatschap staat open voor iedereen die zich vanuit werk of belangstelling aangetrokken voelt tot haar doelen, ongeacht woonplaats of herkomst.

\section{Medisch}

Met 'Medisch' wordt het volledige gebied van de gezondheidszorg bedoeld. 'Medisch' als term is dus niet beperkt tot medici of geneeskunde, maar betreft onderwijs en personen in de gezondheidszorg in het algemeen.

\section{Onderwijs}

Bij de toenemende aandacht voor de medische vervolgopleidingen is wel geopperd om 'Onderwijs' te vervangen door 'Onderwijs en opleiding'. Ook hier is geen verandering aangewezen, omdat 'onderwijs' breed moet worden opgevat. Het betreft het begin van de studie tot aan het einde van de nascholing.

\section{Samenstelling bestuur NVMO}

De zeven bestuursleden worden gekozen door de vereniging, op voordracht van het zittende bestuur of van tenminste tien leden. Bij de samenstelling wordt gelet op diversiteit in deskundigheid op grond van de achtergrond van de bestuursleden. Het bestuur moet gesprekspartner kunnen zijn voor de basisopleiding (prekliniek en kliniek), de vervolgopleidingen, de wereld van de HBOgezondheidszorg, de medische beroepsgroep en voor studenten. Behalve studentleden zijn andere leden niet gespecificeerd. Een brede samenstelling van het bestuur houdt niet noodzakelijk een vertegenwoordiging in vanuit specifieke groepen met last en ruggespraak. Het bestuur heeft twee vaste adviseurs: de hoofdredacteur van het Tijdschrift en de hoofdorganisator van het Congres. Deze leggen verantwoording af aan het bestuur en stemmen hun beleid af met het bestuur.
Ledental

Het is verheugend dat sinds 1972 de vereniging een continue jaarlijkse groei in het ledental laat zien. In september 2007 heeft de NVMO circa 900 leden. Toch moet geconstateerd worden dat, gezien het grote aantal onderwijsinstellingen in Nederland en Vlaanderen en het grote aantal opleiders en supervisoren in de medische vervolgopleidingen, het ledenaantal veel groter kan zijn. Voor een gezonde bedrijfsvoering is een ledental van 1000 tot 1200 gewenst. Vanaf deze grens is het mogelijk de beide belangrijkste activiteiten zelfbedruipend te laten zijn: het Con- gres en het Tijdschrift. Nu wordt het Tijdschrift gedeeltelijk gefinancierd uit opbrengsten van het Congres. Er wordt vooral gestreefd naar een ledentoename onder klinische docenten, zowel degenen die betrokken zijn bij de vervolgopleidingen, als docenten in het universitaire onderwijs; 1500 leden in 2012 lijkt een ambitieuze maar haalbare doelstelling.

\section{Typen lidmaatschappen}

Thans kent de NVMO gewone leden, ereleden, studentleden en donateurs. Ereleden zullen voor het leven benoemd worden en ontheven zijn van contributie. Han Moll laureaten worden automatisch erelid, alsmede oudbestuursvoorzitters. Voorts is er een senior-lidmaatschap, waarbij de contributie gelijk is aan die van studentleden.

\section{Onderzoek van onderwijs}

Het stimuleren van onderzoek van onderwijs is een kernactiviteit van de vereniging. Zowel het Tijdschrift als het Congres biedt daarvoor een platform. Daarnaast kan er echter meer gedaan worden. In oktober 2006 heeft de NVMO voor het eerst een bijeenkomst georganiseerd voor promovendi en hun begeleiders met actieve bijdragen van alle promovendi; in juni 2007 is een tweede succesvolle dag georganiseerd. Hiermee wordt het onderzoek van onderwijs een verdere stimulans gegeven. De dag wordt enerzijds gevormd door bijdragen van alle deelnemende promovendi en anderzijds door enkele gerichte presentaties door experts over methodologische aspecten. Op deze wijze kan de promovendidag uitgroeien tot een vast onderdeel voor opleidings- en begeleidingsplannen, zoals deze gebruikelijk en toenemend verplicht zijn voor aios en andere promovendi. Het bestuur zal voorts ook op andere wijze actief het onderzoeksklimaat in Nederland voor medisch onderwijs research bevorderen. 


\section{Activiteiten}

\section{NVMO-congres}

Het NVMO-congres is een succesvolle activiteit en het bestuur is van oordeel dat de gekozen formule gehandhaafd moet blijven. Wel zal onderzocht worden of het congres kan worden uitgebreid met een 'opleidingsdag', gericht op de vervolgopleidingen.

\section{Tijdschrift voor Medisch Onderwijs}

Het Tijdschrift heeft een gevestigde kwaliteit. De stroom van artikelen kan echter groter zijn, waardoor ook de redactionele speelruimte bij de selectie van artikelen kan toenemen. De oorzaak daarvan is niet dat er onvoldoende artikelen van goede kwaliteit in Nederland worden geschreven, maar dat naar verhouding vooral het percentage publicaties in Engelstalige tijdschriften sterk is toegenomen. Het bestuur zal zich met de redactie beraden op de wijze waarop het TMO van deze toenemende activiteit mee kan profiteren. Wellicht kan gedacht worden aan vertalingen en simultaanpublicaties van internationale artikelen van Nederlandse auteurs. Ook zullen artikelen van het Tijdschrift voor leden elektronisch toegankelijk worden via de website.

\section{Website}

In 2006 is een nieuwe, meer professionele NVMO-website gelanceerd, ondersteund door een webmaster. De website is van grote betekenis voor het contact tussen de leden van de vereniging onderling en tussen het bestuur en de leden.

\section{NVMO-werkgroepen en -commissies}

De NVMO kent commissies die verantwoordelijk zijn voor het Congres en het Tijdschrift en tot voor kort vier werkgroepen, gericht op diverse onderwerpen, die in de loop der jaren door leden van de vereniging als van voldoende belang zijn ge- identificeerd om onder de vlag van de NVMO activiteiten te verrichten.

Het bestuur is voornemens de werkgroepen nog duidelijker status te geven, door enerzijds de werkgroep een jaarlijks budget op basis van een activiteitenplan toe te kennen en anderzijds ook activiteiten te verlangen die voor de vereniging als geheel een bijzondere betekenis hebben. Dat wil zeggen dat de leden van de werkgroepen niet slechts regelmatig bijeenkomen en elkaar informeren, maar dat er ook minimaal eenmaal per jaar een activiteit is, in welke vorm dan ook, die een duidelijke uitstraling heeft naar de vereniging als geheel. Het bestuur zal in het jaarverslag van iedere werkgroep een bijdrage vragen waarin de werkgroepactiviteiten worden verantwoord en zal ook jaarlijks beslissen over de continuering van de subsidie, c.q. over het bestaansrecht van de groep als NVMOwerkgroep. Daarnaast worden leden van de vereniging opgeroepen om, op het terrein waarop dat zinnig lijkt, nieuwe werkgroepen aan het bestuur voor te dragen.

In 2007 heeft dit beleid al duidelijk vrucht afgeworpen. Er zijn thans (september 2007) negen NVMO-werkgroepen, waarvan sommige in oprichting en met naamgeving die nog moet worden vastgesteld: (a) Praktisch Medisch Onderwijs/Medisch Onderwijs in de Praktijk; (b) Computerondersteund Onderwijs/E-learning; (c) Portfolio; (d) Docentenprofessionalisering; (e) Professioneel gedrag; (f) Multiculturaliteit; (g) Curriculumontwikkeling vervolgopleidingen i.o.; (h) Skills en Simulatietechnieken i.o. en (i) Simulatiepatiënten i.o. Het bestuur heeft actief overleg met de werkgroepen en hun activiteiten en beleid; zij ontvangen subsidie indien nodig, hebben een webpagina op de NVMO-website en voeren een transparant beleid. De werkgroepen zijn voor de vereniging de bundeling van expertise en activiteiten op specifieke gebieden.

\section{Internationale oriëntatie}

Nederland is wereldwijd bekend door belangrijke bijdragen aan de ontwikkeling van het medisch onderwijs, zowel in de vorm van artikelen in de internationale literatuur als in de vorm van bijdragen aan internationale congressen. In sommige opzichten vervult Nederland een voorbeeldfunctie. De oriëntatie van de NVMO is altijd sterk nationaal gericht geweest, hoewel recent het Congres enkele buitenlandse bijdragen kent en ook het Tijdschrift Engelstalige samenvattingen van de artikelen publiceert.

Het bestuur stelt thans voor om de internationale oriëntatie van de vereniging, in het buitenland de 'Netherlands Association for Medical Education' (what's in a NAME?), in de komende jaren te versterken. Dat kan door bijvoorbeeld een strategische samenwerking te realiseren met de Association for Medical Education in Europe en haar tijdschrift Medical Teacher, op een wijze die ook de Canadese zustervereniging CAME met AMEE heeft, en met zusterverenigingen in andere landen.

\section{Docentprofessionalisering}

De NVMO acht het niet meer een verenigingstaak om zelf trainingen voor docenten te organiseren, zoals in het verleden wel is gebeurd. Wel zal het bestuur bevorderen dat de NVMO een rol speelt in de erkenning en 
kwalificatie van docenten, zeker waar het landelijke aspecten betreft. De NVMO-werkgroep Docentenprofessionalisering zal op verzoek van het bestuur hiervoor een plan uitwerken. De vereniging behartigt waar mogelijk de belangen van haar leden. Als onderdeel hiervan streeft het bestuur ernaar om de stem van de NVMO hoorbaar te maken in gremia die voor onderwijs en opleiding in de gezondheidszorg belangrijk zijn, waaronder de KNMG en haar colleges, de CBOG, de NFU, de STZ en de NVZ.

\section{Prijzen en erkenningen}

Het bestuur is voornemens in de komende jaren haar waardering voor bijzondere activiteiten van leden op het gebied van onderwijs in de gezondheidszorg sterker tot uitdrukking te brengen in de vorm van prijzen en erkenningen. Dit beleid zal in 2007 gestalte krijgen.

\section{Tot slot}

Plannen zijn plannen, en in 2012 kijken we weer terug. Het huidige bestuur heeft echter ambitie en vertrouwen in een bloeiende toekomst van de vereniging en we merken hetzelfde bij veel leden, die we daarin ook graag stimuleren. En dat is precies het doel van een op de toekomst gericht beleid. Om het handelen in het hier en nu vorm en richting te geven, ongeacht of de doelen nu gehaald, niet gehaald of zelfs voorbijgestreefd worden. Deze vereniging is een uniek gezelschap zoals zich dat in de meeste landen om ons heen niet heeft kunnen ontwikkelen. Laten we er trots op zijn, maar nu aan de slag gaan. 